\title{
ДЕРЖАВНА ПОЛІТИКА РЕГУЛЮВАННЯ РОЗВИТКУ ЗАЛІЗНИЧНОГО ТРАНСПОРТУ УКРАЇНИ
}

\author{
Соломніков І.В., к.е.н., асистент, \\ Островерх Г.С., аспірант(УкрДУЗТ)
}

В статті обтрунтовані та розглянуті проблеми розвитку залізничного транспорту Украӥни та запропоновано удосконалення державного механізму управління розвитком залізничної галузі в умовах структурного реформування для забезпеченні стійких позицій евроінтеграційного вектору, формування конкурентного середовища та стабільного функиіонування галузі. Запропоновано підхід щзодо реалізації механізму державного управління розвитком залізничної галузі Украӥни з визначенням основних иілей.

Ключевые слова: өвроінтеграція, державне управління, залізничний транспорт, розвиток, реформування, залізнична галузь.

\section{ГОСУДАРСТВЕННАЯ ПОЛИТИКА РЕГУЛИРОВАНИЯ РАЗВИТИЯ ЖЕЛЕЗНОДОРОЖНОГО ТРАНСПОРТА УКРАИНЫ}

\author{
Соломников И.В., к.э.н., ассистент, \\ Островерх А.Е., аспирант (УкрГУЖТ)
}

В статье обоснованы и рассмотрены проблемы развития железнодорожного транспорта Украины и предложено усовершенствование государственного механизма управления развитием железнодорожной отрасли в условиях структурного реформирования для обеспечении устойчивых позиций евроинтеграционного вектора, формирование конкурентной среды и стабильного функиионирования отрасли. Предложен подход к реализации механизма государственного управления развитием железнодорожной отрасли Украины с определением основных иелей.

Ключевье слова: еврочнтеграция, государственное управление, железнодорожный транспорт, развитие, реформирование, жжелезнодорожная отрасль.

\section{STATE POLICY OF REGULATION OF DEVELOPMENT OF RAINBOW TRANSPORT OF UKRAINE}

\section{Solomnikov I., candidate of economic sciences, assistant, Ostroverkh H., graduate student (USURT)}

The article substantiates and addresses the problems of the development of rail transport in Ukraine and proposes the improvement of the state mechanism for managing. The development of the railway industry in the conditions of structural reform in order to ensure stable positions of the European integration vector, the formation of a competitive environment and the stable functioning of the industry. The approach to implementation of the

(C) Соломніков I.B., Островерх Г.С. 
mechanism of state management of the development of the railway industry of Ukraine with the definition of the main objectives is proposed.

The general objective of the European integration of the railway transport system is to form a common railroad transport space, which can guarantee a comprehensive result for the railway complex of Ukraine. Its goals are: improved services, interoperability, infrastructure development, and security.

At the same time, solving the problem of forming a common European railway transport space is: supranational (in the person of international transport institutes) and national, which is divided into state, industry level and level of transport enterprises.

The state-run approach, which is now regulated by indifference, and the various methods of uncontrolled support for domestic rail transport enterprises and industries that have created monopolists in the market who do not think about effective service delivery, but the main goal is only to generate profits, even if it is possible to completely destroy the industry, which does not give those results in the development of market relations in the international market. Therefore, it often becomes necessary to determine the main mechanisms of public administration, where the initiative-organizational state component is the only one that can stop the absolute and relative decline of the country's economy and be the starting point for its accelerated growth under the auspices of the state.

Key words: eurointegration, state administration, rail transport, development, reform, railway industry.

Постановка проблеми та іiї зв'язки 3 науковими чи практичними завданнями. На сьогоднішній день держава втратила довіру, функції держави обмежилися i зосередилися суто на фіскальному механізмі перерозподілу податків i бюджету та апаратові легального примусу. Органи влади не займаються активним розвитком економіки, не створюють нові механізми для реалізації можливостей громадян.

В Україні більше панує іноземний капітал, необізнаність, інстинкт споживання та отримання прибутку від власного бізнесу для себе, що призвело до об'єктивних та суб'єктивних причин проблематичного розвитку економіки та ринкових відносин в умовах Євроінтеграції.

Державний підхід, який зараз регулюється байдужістю, та різними методами неконтрольованої підтримки вітчизняних підприємств залізничного транспорту та промислових галузей, що створило монополістів на ринку, які не думають про ефективні надання послуг, а головною метою $\epsilon$ лише отримання прибутку, навіть при можливості повного знищення галузі, що не дає тих результатів у розвитку ринкових відносини на міжнародному ринку. Сама по собі, ринкова економіка, виправдана 3 економічного та морального погляду доти, доки вона повніше та краще за будь-яку іншу економічну систему забезпечує всі потреби суспільства.

Тому часто стає потреба у визначенні основних механізмів державного управління, де ініціативноорганізаційною державною складовою - $\epsilon$ єдине, що може зупинити абсолютне i відносне падіння економіки країни та бути відправною точкою для пришвидшеного іiі зростання під егідою держави.

Аналіз досліджень i публікацій Розуміння актуальності та значимості зміни сучасної державної політики в процесів розвитку залізничного транспорту викликає інтерес багатьох вітчизняних науковців.

Дослідженню інтеграції в транспортному секторі економіки в умовах формування пріоритетів євроінтеграційного розвитку присвятили увагу Дикань В., Овчиннікова В., 
Якименко Н., Матвієнко В., Толстова А. [1-8] та ін.

Окремі пріоритетні напрямки розвитку залізничного транспорту відповідно до міжнародних вимог щодо надійності, швидкості та безпечності перевезень розглядають Данько М., Гненний М., Дейнека О., Бараш Ю., Ейтутіс Г., Ільчук В., Компанієць В., Кірдіна О.[10-16] та ін.

Незважаючи на великий обсяг наукових розробок теоретичного та практичного характеру у сфері державного управління залізничною галуззю України, є потреба подальшого дослідження проблем, що перешкоджають забезпеченню ефективності функціонування та інтеграції вітчизняного залізничного транспорту в європейську транспортну систему.

Мета статті полягає у формуванні комплексної державної політики регулювання для забезпечення ефективності стабільного функціонування та розвитку залізничного транспорту України.

Викладення основного матеріалу. Слід визначити, що сьогодні АТ «Українська залізниця» функціонує в умовах мінливого зовнішнього середовища. Крім того гостро відчувається наявність великої кількості дестабілізуючих внутрішніх факторів.

Саме тому для забезпечення конкурентоспроможності

міжнародному ринку АТ «Українська залізниця» необхідно виділити дієву модель регулювання та управління з боку держави, яка буде базуватися на відповідній концепції.

Концепція державного управління це система ідей, принципів, уявлень, що зумовлюють мету функціонування організації, механізм взаємодії суб'єкта та об'єкта управління, характер взаємодії між окремими ланками його внутрішньої структури, а також необхідний ступінь урахування впливу зовнішнього середовища на розвиток підприємств залізничного транспорту та регулювання внутрішнього середовища для забезпечення балансу підприємств, щоб створити умови при яких основною метою буде задоволення потреб суспільства та отримання прибутку для подальшого ефективного функціонування залізничної галузі, 3 можливістю стійкого положення на міжнародних просторах.

Залізнична галузь України, що являє собою сукупність суб'єктів господарської діяльності незалежно від їх відомчої належності і форм власності, які розробляють продукцію та надають послуги певних видів перевезень. За роки незалежності залізнична галузь в Україні набула нових якісних стимулів для зростання.

Економічна роль залізничного транспорту міститься насамперед у тому, що він $\epsilon$ органічною ланкою кожного виробництва, проводить безперервну й масову доставку всіх видів сировини, палива й продукції з пунктів виробництва в пункти споживання, а також здійснює поділ праці, спеціалізацію й кооперацію виробництва.

Залізничний транспорт - це важливий фактор економічної інтеграції країн і розвитку міжнародної торгівлі. 3 іншого боку, залізничний транспорт сам по собі представляє найбільшу галузь народного господарства. Так, основні фонди транспортного комплексу становлять близько $15 \%$ загальнодержавних, на транспорті трудяться майже $10 \%$ загального числа робітників та службовців [17].

Залізничний транспорт забезпечує вантажні, побутові й туристичні поїздки; полегшує їх фізичну працю, зокрема при переміщенні значних обсягів вантажів та інше.

Залізничний транспорт забезпечує спілкування між континентами, країнами, містами і людьми й сприяє задоволенню їх естетичних потреб і культурному обміну (культурне значення транспорту). Оборонна роль залізничного транспорту 
виділялася й підкреслювалася завжди. 3 недавніх часів залізничний транспорт розглядався як один із найважливіших факторів забезпечення обороноздатності держави.

Його функціями $\epsilon$ перекидання військ і озброєнь, вантажів постачання, забезпечення об'єктів тилових служб і військового виробництва [18].

Під структурою залізничного транспорту розуміється склад, кількісні співвідношення і форми взаємозв'язку окремих галузей i виробництв. Показниками залізничної структури $є$ : число самостійних підприємств, співвідношення усіх видів транспорту в загальному обсязі перевезень вантажів всього транспортного комплексу, частка пасажирського та вантажного транспорту.

На практиці планування та облік залізничної галузі України визначають шляхом знаходження питомої ваги галузей у загальному обсязі транспортного виробництва. Структура залізничної галузі України формується під впливом багатьох факторів.

Розвиток і вдосконалення залізничного транспорту здійснюється відповідно до державних цільових програм з урахуванням його пріоритету та на основі досягнень науково-технічного прогресу і забезпечення цілеспрямованого державного регулювання. Місце і роль залізничного транспорту у суспільному виробництві визначає необхідність його пріоритетного розвитку, державної підтримки в задоволенні його потреб у транспортних засобах, матеріальнотехнічних i паливно-енергетичних pecypcax.

АТ «Українська залізниця» на даний час починає перетворюватися в одну із найбільших в Європі залізничних акціонерних компаній, що займає 5 місце в Європі та 15 у світі за протяжністю інфраструктури, а також відповідно 2 і 5 місця за вантажообігом та 5 i 7 - за пасажирообігом.
Вона виконує 63\% вантажообігу та 34\% пасажирообігу всієї транспортної системи держави, забезпечує робочі місця для майже $1,5 \%$ від чисельності працівників, зайнятих в економіці держави, $\epsilon$ одним із найбільших замовників продукції промисловості на внутрішньому ринку - обсяг його щорічних потреб потенційно сягає 40 млрд. грн.[19].

Та за останній роки справи 3 логістикою, йдуть не кращим чином. Як і раніше, одна із головних проблем $\epsilon$ забезпечення залізничними вагонами, їх не вистачає ні для поставок сировинних ресурсів на підприємства, ні для вивозу вже готової продукції. Крім того, багато нарікань викликає несвоєчасне постачання рухомого складу під завантаження, що також призводить до надзвичайно негативних наслідків як для галузі, так i для всієї країни в цілому. Проте вже зараз зрозуміло, що без створення незалежного органу з боку держави - для регулювання на транспорті, а також комплексної політики розвитку залізничної галузі навряд чи вийде добитися результатів та підняти залізничну галузь України.

За останні роки незалежності України, у зв'язку 3 погіршеним становищем обсяги перевезень залізничним транспортом скоротилися більше ніж у 2 рази (порівняно у 2017 р. із 2013p. вантажообіг зменшився на 52,5\% , пасажирообіг - на 52,3\%).

За цей період експлуатаційна протяжність колій зменшилася на 7\%, середньооблікова чисельність персоналу на $50,8 \%$, експлуатаційний парк локомотивів - майже на 61\%, парк вантажних вагонів - на $60 \%$, парк пасажирських вагонів - на 51\%.

Водночас кількість відокремлених підрозділів 3 ремонту й утримання рухомого складу та інфраструктури не зазнала значних змін і залишилася на рівні, близькому до 2013 р., і складає 338 підрозділів (зменшення на 9\%), кількість станцій - 1510 (зменшення - 25\%) [19] . 
Наведені дані свідчать про наявність певних резервів щодо підвищення продуктивності за рахунок оптимізації структури і підвищення операційної ефективності. Досягнення рівня показників провідних світових компаній потребуватиме технічного та технологічного переозброєння на передових напрямках. Однак все ж $\epsilon$ загрози, які заважають стрімкому, стабільному розвитку залізничного транспорту в Україні.

Основними дестабілізуючими факторами сталого функціонуванню та розвитку АТ «Українська залізниця» $є$ :

1) знос активної частини основних фондів перевищив 90\%. Крім того, $72 \%$ електровозів, $74 \%$ тепловозів, $57 \%$ вантажних та $62 \%$ пасажирських вагонів експлуатується за межами допустимого строку служби. Сума вартості відкладених ремонтів рухомого складу та інфраструктури сягає 36 млрд. грн і продовжує зростати [20];

2) збільшення боргового навантаження АТ «Українська залізниця» внаслідок девальвації національної валюти несе загрозу дефолту та робить проблемним залучення коштів на зовнішньому і внутрішньому ринках;

3) зменшення економічної активності в ключових для АТ «Українська залізниця» східних індустріальних регіонах країни, втрата контролю над об'єктами Донецької залізниці та Криму;

4) зменшення вантажообігу 3 країнами Митного союзу;

5) підвищення вартості операційних витрат на фоні рекордної інфляції в Україні;

6) поточна та прогнозна економічна ситуація в країні, яка характеризується падінням обсягів промислового виробництва (особливо в металургії та вугільній промисловості), несе ризики значного скорочення обсягів вантажних перевезень;
7) втрата конкурентних переваг залізничного транспорту i подальший перехід високодохідних вантажів на інші види транспорту (за 10 років частка залізниць у вантажообігу зменшилась на 5\%) призведе до зменшення дохідної бази АТ «Українська залізниця», що буде вимагати оптимізації (скорочення) мережі залізниць, або їх державної підтримки;

8) необхідність підтримки існуючих соціальних стандартів як для співробітників, так і для населення України [20];

9) недосконалість нормативноправових актів, що регулюють діяльність залізничного транспорту та невідповідність організаційної структури залізничного транспорту тенденціям розвитку ринкової економіки України;

10) наявність перехресного субсидування збиткових пасажирських перевезень за рахунок вантажних;

11) недостатня фінансова прозорість діяльності залізничної галузі; низький рівень конкуренції на ринку залізничних перевезень [21].

Також потрібно звернути увагу на теорію систем управління, яка визначає декілька видів проблем:

1) оперативні проблеми - це проблеми, вирішення яких спрямоване на запобігання, усунення або компенсацію обурень, що порушують поточну діяльність системи. Це структуровані проблеми, вирішення яких пов'язане 3 кількісною їх оцінкою, наявністю добре відпрацьованих альтернативних наборів дій в тій або іншій ситуації;

2) проблеми вдосконалення i розвитку систем -це проблеми, вирішення яких спрямоване на підвищення ефективності функціонування шляхом зміни характеристик об'єкта управління або системи управління об'єктом, а також упровадження нових ідей. Це слабо структуровані проблеми, вирішення яких $є$ об'єктом дослідження системного аналізу і синтезу; 
3) інноваційні проблеми - це проблеми, вирішення яких пов'язане 3 розробкою нових ідей i упровадженням нововведень. Це дуже слабо структуровані (або неструктуровані) проблеми. Їх вирішення пов'язане з породженням нових ідей і застосуванням евристичних методів на основі досвіду й інтуїції.

Проблема інтеграції вітчизняного залізничного транспорту в європейську транспортну мережу варто віднести до такої, що поєднує риси проблеми вдосконалення і розвитку та інноваційної проблеми. При цьому той факт, що вирішення зазначеної проблеми спрямоване на стабілізацію та вдосконалення функціонування системи (залізнична транспортна система), що має ієрархічну структуру, обумовлює ієрархічність і самої проблеми. Виявляється вона не тільки в тому, що проблема євроінтеграції залізничного транспорту України $є$ сукупністю підпроблем, але і в тому, що вона може розглядатися як частина (підпроблема) більш крупної проблеми (Свроінтеграція України). [22]

Україні потрібні нові механізми державного управління. Розробки i впровадження таких механізмів потребує i залізнична галузь України. Так, комплексна політика державного регулювання має враховувати пріоритетні напрями розвитку галузі, розкриваючи інструменти формування суттєвих переваг за складовими розвитку, як економічна, інноваційна, виробнича, інвестиційна, соціальна, енергетична, екологічна та міжнародна складова (рис.1).

Механізми державного управління комплексної політики розвитку залізничної галузі повинні бути направлені на реалізацію економічних, організаційних, нормативно-правових i мотиваційних заходів 3 розвитку. Одним із головних суб' єктів комплексної політики розвитку залізничної галузі, поряд 3 державою, повинен стати споживач, держава, власник компаній перевізників та пасажири.
Перш за все, доцільно розробити механізм прямого державного кредитування АТ «Українська залізниця», одноосібних чи сімейних господарств, товаровиробників без застави та за відсотками й комісіями, що передбачають лише відновлення витрат кредитних установ в межах 3-5\%. Разом 3 цим, важливу роль буде відігравати спрощення і пришвидшення отримання дозвільної документації на перевезення.

Актуальність цих механізмів в тому, що, на жаль, іноземний капітал, існуючий управлінський апарат АТ «Українська залізниця» не зацікавлені і неспроможні в формуванні первинного товаровиробника i отримання більшого доходу від перевезень для країни, та покращення послуг для суспільства. Не зацікавлені вони і у появі у підприємств залізничного транспорту, достатнього рівня забезпеченості, як у вигляді роботи, так і достойної оплати результатів цієї роботи.

Необхідні механізми державного управління в комплексній політиці розвитку залізничного транспорту направлені на формування кооперації між товариствами власників землі та міжгалузевої кооперації - між товариствами i національними виробниками, необхідної для залізничної галузі, які багаторазово збільшать ефект від розвитку галузі.

у такому запропонованому комплексною політикою розвитку залізничної галузі, для інтенсивного режиму організації розвитку залізниць України, важливим завданням буде забезпечення збільшення споживання продукції первинного виробника, не тільки на внутрішньому ринку, a i інтенсивне просування українських перевезень на зовнішні ринки, що спростить вихід на міжнародний ринок.

Для забезпечення цього необхідний механізм захисту власного виробника та експортної орієнтації розвитку галузі через експортно-кредитну функцію (страхування та підтримку). 


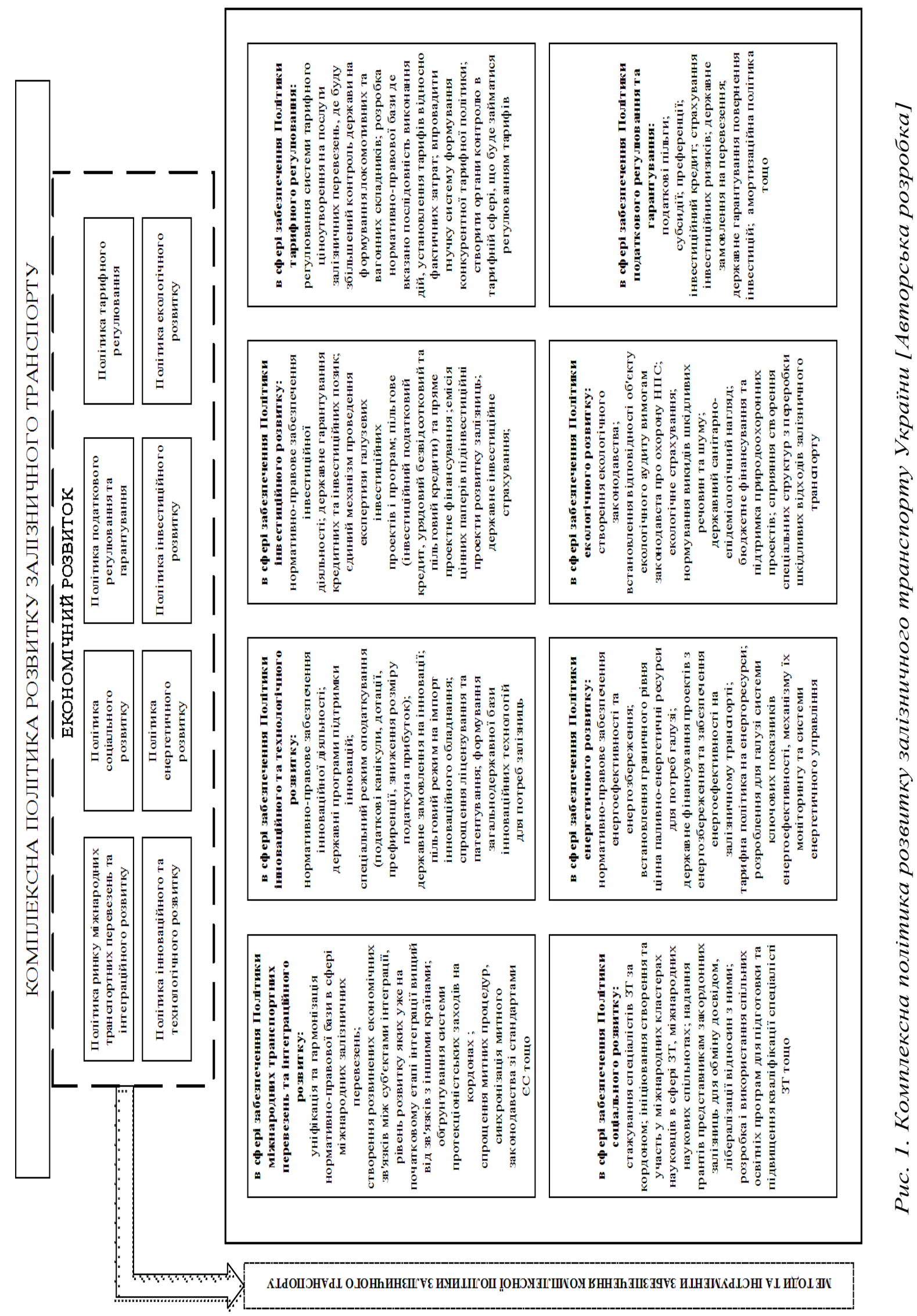




\section{Висновок Загальна мета} євроінтеграції залізничної транспортної системи - це формування спільного залізничного транспортного простору, що може гарантувати отримання комплексного результату для залізничного комплексу України. Ії̈ цілями є: удосконалення послуг, забезпечення експлуатаційної сумісності, розвиток інфраструктури, забезпечення безпеки.

Рівнями вирішення проблеми формування спільного європейського залізничного транспортного простору $\epsilon$ : наднаціональний (в особі міжнародних інститутів транспорту) та національний, що розподіляється на державний, галузевий рівні та рівень підприємств транспорту.

Сучасна державна політика в сфері регулювання залізничної галузі в Україні потребує жорсткого реформування відповідно до норм Європейського Союзу. У зв'язку 3 зазначеним обгрунтовано необхідність удосконалення системи управління залізничним транспортом та забезпечення державної підтримки його реформування, що дозволить підвищити конкурентоспроможність українських залізниць на ринку транспортних послуг.

Формування державної політики розвитку залізничної галузі в умовах євроінтеграційного процесу дозволять вирішити наукову задачу щодо удосконалення механізму державного управління залізничної галузі України. За рахунок розширення організаційноекономічного та ресурсного інструментарію.

\section{ПЕРЕЛІК ВИКОРИСТАНИХ ДЖЕРЕЛ}

1 Дикань В. Л. Державне регулювання промислового розвитку України / В. Л. Дикань, М. В. Корінь // Вісник економіки транспорту і промисловості. - 2018. - №. 61- С.9-19.

2 Дикань В.Л. Сутнісні аспекти конкурентоспроможності національної економіки / В.Л. Дикань, О.Г. Кірдіна //
Вісник економіки транспорту i промисловості. - 2009. - № 28. - С. 13-20.

3 Дикань В.Л. Механізм створення залізнично-транспортнопромислової групи в сучасних умовах розвитку залізничного транспорту України / В.Л. Дикань, М.В. Кондратюк // Вісник економіки транспорту і промисловості. 2009. - № 26. - C. 13-18.

4 Дикань В.Л. Удосконалення механізмів державного управління розвитком залізничної галузі України у євро інтеграційному просторі/ В.Л. Дикань, Г.С. Островерх // Вісник економіки транспорту i промисловості : збірник наукових праць. - Х. : УкрДУЗТ, 2018. № 62. - С. 11-19.

5 Овчиннікова В.О. Стратегічне управління розвитком залізничного транспорту України: монографія / B.О. Овчиннікова. - Х. : УкрДУЗТ, 2017. -427 с.

6 Якименко Н. В. Методологічні основи державного регулювання розвитку залізничного транспорту України / Н. В. Якименко. // Вісник економіки транспорту і промисловості. - 2010. - №31. - С. 197-202.

7 Матвієнко В.В. Державний механізм реформування залізничної галузі: європейський досвід / В.В. Матвієнко // Сучасні проблеми державного управління в умовах системних змін. Серія: Державне управління: зб. наук. пр. - Маріуполь: ДонДУУ, 2015. - Т. XVI. - Вип. 297. С.122-132.

8 Толстова А.В. Роль державного регулювання в процесі детінізації економіки України / А.В. Толстова // Вісник економіки транспорту і промисловості. - 2012. - №40. C. 303-306.

9 Данько М. I. Транспортнологістична система в межах міжнародних транспортних коридорів та іï вплив на транзитні можливості України / М. І. Данько // Вісник економіки транспорту і промисловості. - 2011. - № 34. - С. 15-16.

$$
10 \text { Економіка залізничного }
$$
транспорту [Текст]: підручник за ред. І.Ю.Кулаєв, Ю. С. Бараша, М. В. Гненного; Дніпропетр. нац. ун-т залізн. трансп. ім. 
акад. В. Лазаряна. - Дніпропетровськ, 2014.$480 \mathrm{c}$.

11 Дейнека О. Г. Теоретичні та методологічні складові розвитку залізничного транспорту України // Вісник економіки транспорту і промисловості. 2009. - №. 25. - С. 62-65.

12 Бараш Ю.С. Управління залізничним транспортом країни: 2-е вид.,перероб. і доп / Ю.С. Бараш. Дніпропетровськ.- 2006. - 259 с.

13 Ейтутіс Г. Потенційні джерела інвестування в розвиток залізничного транспорту України: можливості їх диверсифікації / Г. Ейтутіс, О. Никифорук, О. Бойко // Економіст. - 2012. - №8. C. 64-69.

14 Ільчук В. П. Інноваційноінвестиційна система залізничного транспорту як економічна категорія / В. П. Ільчук, Є. М.Сич // - Київ : Логос, 2001. - 256 c.

15 Компанієць В. В. Стратегія людського розвитку та зміни у підготовці кадрів залізничного транспорту / В. В. Компанієць // Вісник економіки транспорту та промисловості. - №31.- 2010.- С.203-211.

16 Кірдіна О.Г. Необхідність науково-виробничої інтеграції як форми реалізації інвестиційно-інноваційного проекту організації швидкісного рухузалізницями України / О. Г. Кірдіна // Вісник ХНАУ. -2010. - № 10. - С. 183-194.

17 Про затвердження Державної програми активізації розвитку економіки на 2013-2014 роки [Електронний ресурс] : Постанова Кабінету Міністрів України від 27 лютого 2013 р. №187 // Законодавство / Верховна Рада України. - Електрон. текст. дані. - Київ, 2013. - Режим доступу: http://zakon5.rada.gov.ua/laws/show/187-2013\%D0\%BF (дата звернення: 22.11.2016).

18 Галабурда В. Г. Единая транспортная система / В. Г. Галабурда. Москва: Транспорт, 2001. - 303 с.

19 Довідник основних показників роботи регіональних філій ПАТ «Українська залізниця» (2002-2017 роки). -
Київ: ПАТ «Українська залізниця». Управління статистики, 2018. - 39 с.

20 Островерх Г.С. Стратегічні орієнтири розвитку підприємств залізничного транспорту України / Г.С. Островнрх // Вісник економіки транспорту та промисловості Збір наук. праць. - Харків, УкрДУЗТ, 2016. - № 55. - С. 58-63

$$
21 \text { Сущенко Р. Розвиток }
$$

залізничного транспорту в Україні: проблеми державного регулювання [Електронний ресурс] / P. Сущенко / Дніпропетровський регіональний інститут державного управління. - Електрон. аналог друк. вид.: режим доступу: www.dridu.dp.ua/vidavnictvo/.../12srvpdr.pdf (дата звернення: 22.11.2016).

22 Орлова В.M. Проблема Євроінтеграції вітчизняного залізничного транспорту в контексті теорії систем управління / В.М.Орлова// -Режим доступу: http://vuzlib.com.ua/articles/book/6619-

Problema_\%D1\%94vro\%D1\%96ntegra\%D1\% 81\%D1\%96\%D1\%97_v/1.html

23 Токмакова I.В. Дослідження сутності стійкого розвитку залізничного транспорту / I.В. Токмакова // Вісник економіки транспорту і промисловості. 2010. - №29. - C.227-229.

24 Заєць Г.П. Компетентність як складова характеристики трудового потенціалу підприємств залізничного транспорту / Г.П. Заєць // Вісник економіки транспорту та промисловості Збір наук. праць. - Харків, УкрДУЗТ, 2017. - № 59. C. 117-122.

25 Каличева Н. Є. Активізація діяльності державних інститутів в процесах реформування залізничного транспорту / $\mathrm{H}$. Є Каличева. О. Ю. Чередниченко //Вісник економіки транспорту і промисловості. 2018. - №. 64. - C. 222-231.

26 Соломніков, I.В. Інвестиційне забезпечення техніко-технологічного оновлення підприємств залізничного транспорту / І.В. Соломніков // Вісник економіки транспорту і промисловості. 2017. - № 60, С. 223 -228. 


\section{REFERENCES}

1 Dykanj V. L. Korinj M. V. (2018) Derzhavne reghuljuvannja promyslovogho rozvytku Ukrajiny [State regulation of industrial development of Ukraine]. Bulletin of the Economy of Transport and Industry, no. 61, pp.9-19.

2 Dykanj V.L., Kirdina O.Gh. (2009) Sutnisni aspekty konkurentospromozhnosti nacionaljnoji ekonomiky [Essential aspects of the competitiveness of the national economy].Bulletin of the Economy of Transport and Industry, no. 28, pp.13-20.

3 Dykan V.L., Kondratjuk M.V. (2009) Mekhanizm stvorennja zaliznychnotransportno-promyslovoji ghrupy v suchasnykh umovakh rozvytku zaliznychnogho transportu Ukrajiny [Mechanism of creation of railwaytransport-industrial group in the modern conditions of development of railway transport of Ukraine]. Bulletin of the Economy of Transport and Industry, no.26, pp. 13-18.

4 Dykan V.L., Ostroverkh Gh.Je. (2018) Udoskonalennja mekhanizmiv derzhavnogho upravlinnja rozvytkom zaliznychnoji ghaluzi Ukrajiny $u$ jevro integhracijnomu prostori [Improvement of the mechanisms of state governance for the development of the railway industry of Ukraine in the euro integration space]. Bulletin of the Economy of Transport and Industry, no. 62, pp. 11-19.

5 Ovchynnikova V.O. (2017) Strateghichne upravlinnja rozvytkom zaliznychnogho transportu Ukrajiny: monoghrafija [Strategic management of railway transport development in Ukraine: monograph] Kharkiv: UkrDUZT (in Ukraine).

6 Jakymenko N. V. (2010) Metodologhichni osnovy derzhavnogho reghuljuvannja rozvytku zaliznychnogho transportu Ukrajiny [Methodological bases of state regulation of the development of railway transport of Ukraine]. Bulletin of the Economy of Transport and Industry, no. 31, pp. 197-202.

7 Matvijenko V.V. (2015) Derzhavnyj mekhanizm reformuvannja zaliznychnoji ghaluzi: jevropejsjkyj dosvid [State Mechanism for Reforming the Railway Industry: European Experience]. Modern problems of state administration in conditions of systemic changes. Series: Public Administration: Sb. sciences Ave, no. 297, pp.122-132.

8 Tolstova A.V. (2012) Rolj derzhavnogho reghuljuvannja $\mathrm{V}$ procesi detinizaciji ekonomiky Ukrajiny [The role of state regulation in the process of shadowing of the economy of Ukraine]. Bulletin of the Economy of Transport and Industry, no.40, pp. 303-306.

9 Danjko M.I. (2011) Transportnologhistychna systema $\mathrm{V}$ mezhakh mizhnarodnykh transportnykh korydoriv ta jiji vplyv na tranzytni mozhlyvosti Ukrajiny [Transport and logistics system within the international transport corridors and its influence on the transit possibilities of Ukraine]. Bulletin of the Economy of Transport and Industry, no. 34, pp.15-16.

10 I.Ju.Kulajev, Ju. S. Barasha, M. V. Ghnennogho (2014) Ekonomika zaliznychnogho transportu [Economics of rail transport]. Dnipropetrovsjk: Dnipropetr. nac. un-t zalizn. transp. im. akad. V. Lazarjana (in Ukraine).

11 Dejneka O. Gh. (2009) Teoretychni ta metodologhichni skladovi rozvytku zaliznychnogho transportu Ukrajiny [Theoretical and methodological components of the development of rail transport in Ukraine]. Bulletin of the Economy of Transport and Industry, no. 25, pp. 62-65.

12 Barash Ju.S. (2006) Upravlinnja zaliznychnym transportom krajiny: 2-e vyd.,pererob. [Railroad Transport Management of the country: 2 nd type. Recycling. and dop]. Dnipropetrovsjk: Dnipropetr. nac. un-t zalizn. transp. im. akad. V. Lazarjana (in Ukraine).

13 Ejtutis Gh., O. Nykyforuk, O. Bojko (2012) Potencijni dzherela investuvannja $\mathrm{v}$ rozvytok zaliznychnogho transportu Ukrajiny: mozhlyvosti jikh dyversyfikaciji [Potential sources of investment in the development of rail transport in Ukraine: the possibilities of their diversification]. Ekonomist, no. 8, pp. 64-69. 
14 Iljchuk V., M.Sych P. Je. (2001) Innovacijno-investycijna systema zaliznychnogho transportu jak ekonomichna kateghorija [Innovative-investment system of railway transport as an economic category] Kyiv: Logos (in Ukraine).

15 Kompanijecj V. V. (2010) Strateghija ljudsjkogho rozvytku ta zminy u pidghotovci kadriv zaliznychnogho transportu [Human Development Strategy and Changes in the Training of Trainers in Railway Transport]. Bulletin of the Economy of Transport and Industry, no. 31, pp. 203-211.

16 Kirdina O.Gh. (2010) Neobkhidnistj naukovo-vyrobnychoji integhraciji jak formy realizaciji investycijnoinnovacijnogho proektu orghanizaciji shvydkisnogho rukhuzaliznycjamy Ukrajiny [Necessity of scientific and industrial integration as a form of realization of investment-innovative project of organization of high-speed traffic by railways of Ukraine]. Visnyk KhNAU, no.10, pp.183-194.

17 Pro zatverdzhennja Derzhavnoji proghramy aktyvizaciji rozvytku ekonomiky na 2013-2014 roky [Elektronnyj resurs] : Postanova Kabinetu Ministriv Ukrajiny vid 27 ljutogho 2013 r. \#187 // Zakonodavstvo / Verkhovna Rada Ukrajiny. - Elektron. tekst. dani. - Kyjiv, 2013. - Rezhym dostupu: http://zakon5.rada.gov.ua/laws/show/187-2013\%D0\%BF (data zvernennja: 22.11.2016).

18 Ghalaburda V. Gh. Edynaja transportnaja systema (2001) [Uniform transport system] Moskva: Transport (in Russian).

19 (2018) Dovidnyk osnovnykh pokaznykiv roboty reghionaljnykh filij PAT «Ukrajinsjka zaliznycja» (2002-2017 roky)[ Directory of key indicators of regional branches of PJSC "Ukrainian Railways" (2002-2017 years)], Kyjiv: PAT «Ukrajinsjka zaliznycja». Upravlinnja statystyky (in Ukraine).

20 Ostroverkh Gh.Je. (2016) Strateghichni orijentyry rozvytku pidpryjemstv zaliznychnogho transportu Ukrajiny [Strategic guidelines for the development of rail transport enterprises in Ukraine]. Bulletin of the
Economy of Transport and Industry, no.55, pp. 58-63.

21 Sushhenko R. (2016) Rozvytok zaliznychnogho transportu $\mathrm{V}$ Ukrajini: problemy derzhavnogho reghuljuvannja [Development of rail transport in Ukraine: problems of state regulation] Dnipropetrovsjkyj reghionaljnyj instytut derzhavnogho upravlinnja. Available at: www.dridu.dp.ua/vidavnictvo/.../12srvpdr.pdf. 22 Orlova V.M. Problema Jevrointeghraciji vitchyznjanogho zaliznychnogho transportu v konteksti teorijisystem upravlinnja [The problem of the European integration of domestic rail transport in the context of the theory management systems] Available at: http://vuzlib.com.ua /articles/book/6619Problema_\%D1\%94vro\%D1\%9 6ntegra\%D1\%81\%D1\%96\%D1\%97_v/1.html.

$$
23 \text { Tokmakova I.V.(2010) }
$$

Doslidzhennja sutnosti stijkogho rozvytku zaliznychnogho transportu [Investigation of the essence of sustainable development of railway transport]. Bulletin of the Economy of Transport and Industry, no.29, pp.227-229.

$$
24 \text { Zajecj }
$$

Kompetentnistj jak skladova kharakterystyky trudovogho potencialu pidpryjemstv zaliznychnogho transportu [Competence as a component of the labor potential of enterprises of railway transport]. Bulletin of the Economy of Transport and Industry, no.59, pp. 117-122. 25
Kalycheva
$\mathrm{N}$.
Je.,

Cherednychenko O. Ju. (2018) Aktyvizacija dijaljnosti derzhavnykh instytutiv $\mathrm{v}$ procesakh reformuvannja zaliznychnogho transportu [Activation of State Institutions' Activities in the Process of Reforming Railway Transport]. Bulletin of the Economy of Transport and Industry, no.64, pp.222-231.

26 Solomnikov I.V. (2017) Investycijne zabezpechennja tekhnikotekhnologhichnogho onovlennja pidpryjemstv zaliznychnogho transportu transportu [Investment support of the technical and technological update of the railway transport enterprises]. Bulletin of the Economy of Transport and Industry, no.60, pp. 223 -228. 